\title{
MENTAL HEALTH OF SWANSEA'S OLD FOLK
}

\author{
BY \\ P. L. PARSONS* \\ Department of Psychiatry, General Infirmary, Leeds
}

The health of an ever-ageing population is one of the major problems facing our society. In particular, the chance of developing a psychiatric illness requiring hospital admission increases so rapidly with advancing age (Registrar General, 1955) that knowledge of the prevalence of serious psychiatric illness in the elderly living in the community is essential if there is to be effective planning of the country's psychiatric services. It is also important to know what social and other health factors are associated with such illness. This study is a contribution to such knowledge.

A survey aiming to examine the physical and mental health of a random sample of elderly people living in their own homes was carried out in Swansea during the summer of 1961 . The survey was part of a larger social research programme carried out between April, 1960, and September, 1962, and was financed by the Joseph Rowntree Memorial Trust. This paper deals only with the mental health of the sample. The general results of the health survey will be published separately.

\section{SAMPle}

The full research programme was concerned with a 2 per cent. sample of the population of the county borough of Swansea, which had a total population of 167,322 at the 1961 census, of whom 19,447 were 65 and over. The sample was drawn randomly from the electoral register published in March, 1960. This yielded a list of 381 persons aged 65 or over. Since this number was considered to be too great to be visited by one psychiatrist a random sub-sample of 271 was drawn from the original 381. These 271

* Formerly Medical Research Officer, Social Science Department, University College, Swansea. persons constituted the medical sample, of whom 228 were examined ( 27 of the sample were dead and 16 refused to co-operate or were not traced). The sample, although small, is reasonably representative so far as age, sex, and marital state are concerned, when compared with the 1961 census figures (Tables I, II).

TABLE I

SAMPLE COMPARED FOR AGE AND SEX WITH THE 1961 CENSUS

\begin{tabular}{|c|c|c|c|c|c|c|}
\hline \multirow{2}{*}{ Sex } & \multirow{2}{*}{$\begin{array}{l}\text { Age } \\
\text { (yrs) }\end{array}$} & \multicolumn{2}{|c|}{$\begin{array}{l}\text { At Medical Survey } \\
\text { May-Oct., } 1961\end{array}$} & \multicolumn{2}{|c|}{$\begin{array}{l}\text { At Social Survey } \\
\text { May-June, } 1960\end{array}$} & \multirow{2}{*}{$\begin{array}{c}1961 \\
\begin{array}{c}\text { Census } \\
\text { Data }\end{array} \\
\text { Per cent. }\end{array}$} \\
\hline & & No. & Per cent. & No. & Per cent. & \\
\hline \multirow[t]{2}{*}{ Male } & \multirow[t]{2}{*}{$\begin{array}{l}65-69 \\
70-74 \\
75-79 \\
80-84 \\
85+\end{array}$} & $\begin{array}{r}27 \\
44 \\
18 \\
7 \\
3\end{array}$ & $\begin{array}{r}11 \cdot 9 \\
19 \cdot 3 \\
7 \cdot 9 \\
3 \cdot 0 \\
1 \cdot 3\end{array}$ & $\begin{array}{r}35 \\
40 \\
16 \\
5 \\
3\end{array}$ & $\begin{array}{r}15 \cdot 4 \\
17 \cdot 5 \\
7 \cdot 0 \\
2 \cdot 2 \\
1 \cdot 3\end{array}$ & $\begin{array}{r}15 \cdot 9 \\
11 \cdot 2 \\
7 \cdot 0 \\
3 \cdot 3 \\
1 \cdot 4\end{array}$ \\
\hline & & 99 & $43 \cdot 4$ & 99 & $43 \cdot 4$ & $38 \cdot 8$ \\
\hline \multirow[t]{2}{*}{ Female } & \multirow[t]{2}{*}{$\begin{array}{l}65-69 \\
70-74 \\
75-79 \\
80-84 \\
85+\end{array}$} & $\begin{array}{r}36 \\
39 \\
23 \\
23 \\
8\end{array}$ & $\begin{array}{r}15 \cdot 8 \\
17 \cdot 1 \\
10 \cdot 1 \\
10 \cdot 1 \\
3 \cdot 5\end{array}$ & $\begin{array}{r}39 \\
42 \\
21 \\
20 \\
7\end{array}$ & $\begin{array}{r}17 \cdot 1 \\
18 \cdot 4 \\
9 \cdot 2 \\
8 \cdot 8 \\
3 \cdot 1\end{array}$ & $\begin{array}{r}22 \cdot 4 \\
17 \cdot 2 \\
11 \cdot 8 \\
6 \cdot 9 \\
2 \cdot 9\end{array}$ \\
\hline & & 129 & $56 \cdot 6$ & 129 & $56 \cdot 6$ & $61 \cdot 2$ \\
\hline
\end{tabular}

TABle II

SAMPLE COMPARED FOR MARITAL STATE WITH THE 1961 CENSUS

\begin{tabular}{|c|c|c|c|c|c|}
\hline \multirow{2}{*}{$\underset{\text { Status }}{\text { Marital }}$} & & \multicolumn{2}{|c|}{ Male } & \multicolumn{2}{|c|}{ Female } \\
\hline & & $\begin{array}{c}\text { Medical } \\
\text { Sample } \\
\text { (Per cent.) }\end{array}$ & $\begin{array}{c}\text { Census } \\
\text { (Per cent.) }\end{array}$ & $\begin{array}{c}\text { Medical } \\
\text { Sample } \\
\text { (Per cent.) }\end{array}$ & $\begin{array}{c}\text { Census } \\
\text { (Per cent.) }\end{array}$ \\
\hline $\begin{array}{l}\text { Single .. } \\
\text { Married . } \\
\text { Widowed } \\
\text { Other .. }\end{array}$ & $\begin{array}{l}\cdots \\
\cdots \\
\cdots\end{array}$ & $\begin{array}{r}3 \cdot 1 \\
32 \cdot 0 \\
7 \cdot 5 \\
0 \cdot 9\end{array}$ & $\begin{array}{r}3 \cdot 3 \\
26 \cdot 7 \\
8 \cdot 7 \\
0 \cdot 1\end{array}$ & $\begin{array}{r}6 \cdot 6 \\
17 \cdot 9 \\
32 \cdot 0 \\
-\end{array}$ & $\begin{array}{r}7 \cdot 7 \\
19 \cdot 6 \\
33 \cdot 7 \\
0 \cdot 2\end{array}$ \\
\hline Total .. & . & $43 \cdot 5$ & $38 \cdot 8$ & $56 \cdot 5$ & $61 \cdot 2$ \\
\hline
\end{tabular}




\section{Procedure}

Most of the subjects were visited in their homes without prior notification since it was found that an official introductory letter sent through the post caused more anxiety and a higher refusal rate than when an unheralded personal approach was made. The visit varied in length from three-quarters of an hour to two and three-quarter hours, with a mean duration of just over one and a half hours. At the visit a questionnaire on physical and mental health, a Paired Associates Learning Test (PALT) (Inglis, 1959) and the short form of the Maudsley Personality Inventory (MPI) were completed. A relative was interviewed, and whenever possible this was a younger relative who was seen alone. A superficial physical examination was carried out and specimens of urine and blood were collected.

\section{RESULTS}

\section{Memory and Learning Ability}

After asking questions designed to test immediate, recent, and remote memory, the psychiatrist allocated each subject to one of the four groups shown in Table III. Once this clinical estimate had been recorded it was never subsequently altered. The learning test was always administered late in the interview. Ideally, the test should perhaps have been adiministered by a different person, but since the subjects had already been visited twice in relation to the main part of the survey it was felt that more than one extra visit would increase the refusal rate. Table III compares the clinical estimate with the learning test scores in the 214 subjects who were able and willing to complete the test. The scores represent the total number of times each of three pairs of words had to be presented to the subjects before they had learned them sufficiently well to give three consecutive correct responses for each stimulus word, or until each stimulus word had been presented 31 times. Thus the range of scores is from 3 to 93 and the lower score indicates good learning ability. Crossvalidation and cross-cultured validation of this test has been demonstrated (Caird, Sanderson, and Inglis, 1962).

The distribution of the scores does not follow a normal curve, so the U-test developed by Mann and Whitney (1947) was used to test the significance of the difference between groups. This employs the median score instead of the mean. However, since the latter is more familiar, the values for both are given in Table III.

The U-test shows that Groups 1 and 2 differ significantly at the 0.03 level and that Groups 2 and 3 and Groups 3 and 4 differ significantly at the 0.01
TABLE III

CLINICAL ASSESSMENT OF MEMORY COMPARED WITH LEARNING TEST SCORES

\begin{tabular}{c|c|c|c|c|c}
\hline Group & \multicolumn{1}{|c|}{$\begin{array}{c}\text { Psychiatrist's } \\
\text { Assessment }\end{array}$} & $\begin{array}{c}\text { Total } \\
\text { No. of } \\
\text { Cases }\end{array}$ & $\begin{array}{c}\text { No. } \\
\text { comple- } \\
\text { ting } \\
\text { PALT }\end{array}$ & Mean & Median \\
\hline 1 & Normal memory & 146 & 141 & $17 \cdot 4$ & $13 \cdot 6$ \\
\hline 2 & $\begin{array}{l}\text { Slightly impaired } \\
\text { memory }\end{array}$ & 50 & 48 & $23 \cdot 1$ & $18 \cdot 0$ \\
\hline 4 & $\begin{array}{l}\text { Definitely forgetful } \\
\text { Demented, i.e., } \\
\text { cognitive impair- } \\
\text { ment of such a } \\
\text { degree as to } \\
\text { impossible }\end{array}$ & 22 & 19 & $42 \cdot 3$ & $38 \cdot 0$ \\
\hline & $\begin{array}{c}\text { Total } \\
\text { Total }\end{array}$ & 10 & 6 & $81 \cdot 2$ & $93 \cdot 0$ \\
\hline
\end{tabular}

level. The opinions of the psychiatrically untrained lay interviewers did not correlate significantly with the test scores, nor, as perhaps might be expected, did the opinions of the relatives.

We now have an indication of the norm for age and sex as estimated quantitatively by the learning test scores (Table IV). Since we are not examining the data for significant differences between age groups, the mean rather than the median score is given.

TABLE IV

LEARNING TEST SCORES RELATED TO AGE AND SEX

\begin{tabular}{|c|c|c|c|c|c|c|}
\hline \multirow{2}{*}{ Sex } & \multirow{2}{*}{$\begin{array}{c}\text { Age } \\
\text { (yrs) }\end{array}$} & \multirow{2}{*}{$\begin{array}{l}\text { Mean } \\
\text { PALT } \\
\text { Score }\end{array}$} & \multirow{2}{*}{$\begin{array}{c}\text { Total } \\
\text { Sample }\end{array}$} & \multirow{2}{*}{$\begin{array}{l}\text { Number } \\
\text { comple- } \\
\text { ting } \\
\text { PALT }\end{array}$} & \multicolumn{2}{|c|}{$\begin{array}{l}\text { Refused, Failed to } \\
\text { Complete, or Unable } \\
\text { to Attempt PALT }\end{array}$} \\
\hline & & & & & $\begin{array}{l}\text { Clinically } \\
\text { Forgetful }\end{array}$ & $\begin{array}{l}\text { Not } \\
\text { Clinically } \\
\text { Forgetful }\end{array}$ \\
\hline \multirow[t]{2}{*}{ Male } & $\begin{array}{l}65-69 \\
70-74 \\
75-79 \\
80+\end{array}$ & $\begin{array}{l}19 \cdot 7 \\
20 \cdot 3 \\
22 \cdot 9 \\
20 \cdot 0\end{array}$ & $\begin{array}{l}27 \\
44 \\
18 \\
10\end{array}$ & $\begin{array}{r}27 \\
44 \\
16 \\
9\end{array}$ & $\begin{array}{l}0 \\
0 \\
1 \\
1\end{array}$ & $\begin{array}{l}0 \\
0 \\
1 \\
0\end{array}$ \\
\hline & Total & $20 \cdot 6$ & 99 & 96 & 2 & 1 \\
\hline \multirow[t]{2}{*}{ Female } & $\begin{array}{l}65-69 \\
70-74 \\
75-79 \\
80+\end{array}$ & $\begin{array}{l}17 \cdot 1 \\
21 \cdot 1 \\
21 \cdot 8 \\
40 \cdot 0\end{array}$ & $\begin{array}{l}36 \\
39 \\
23 \\
31\end{array}$ & $\begin{array}{l}35 \\
35 \\
20 \\
28\end{array}$ & $\begin{array}{l}0 \\
1 \\
1 \\
3\end{array}$ & $\begin{array}{l}1 \\
3 \\
2 \\
0\end{array}$ \\
\hline & Total & $19 \cdot 4$ & 129 & 118 & 5 & 6 \\
\hline
\end{tabular}

The mean score increased steadily with age up to 79 years, with little difference between the sexes. After 80 , however, there was a striking change; the men who had survived this age had a mean score comparable with the men aged 65-79, whereas the women's mean score rose to 40 , which is of the same order as the mean score for the group that the psychiatrist classified as definitely forgetful (Group 3). 
In this sample 9 of the 10 dements were women. The relative longevity of women is clearly an important factor, but it would also appear that fewer of the men who survive to the age of 80 exhibit gross senile mental changes. Only one of the 10 men aged 80 and over scored $40+$ on the learning test, or was untestable, compared with 14 of the 31 women. However, it would be unwise to generalize on the basis of such small numbers.

It is well known that the admission rate to mental hospitals for senile psychosis is twice as high in women as in men, but it is not clear whether this reflects the situation in the community. There may well be a sex differential in liability to hospital admission. The female role is very much concerned with interpersonal relationships within the extended family and this continues into old age. The male role is different and it changes at retirement; so it is possible that a family will more readily tolerate a mother who is becoming demented than a similarly affected father, because the bonds will tend to be closer. The same factor may operate in relation to admission to old people's homes. It is possible, therefore, that the men over 80 in this sample constitute a highly selected group.

Sheldon (1948), surveying a random sample of the elderly living at home in Wolverhampton in 1945, found that only 1 per cent. were demented, while the proportion of dements in Swansea was $4 \cdot 4$ per cent. However, Sheldon had no special psychiatric experience and there is reason to believe that his figure was an underestimate. The figure of 4.4 per cent. demented is in close agreement with that found by the New York State Mental Health Research Unit under the directorship of E. M. Gruenberg (1961) when they examined the elderly in various census tracts in Syracuse. Kay, Beamish, and Roth (1964) also report a similar figure from their examination of a random sample of 300 people aged 65 and over living at home in certain areas of Newcastle upon Tyne.

\section{Factors associated with the Cognitive State}

A number of health and social factors were found to be related to impairment of memory. The PALT test scores were grouped into three arbitrary categories: less than 10,10-29, and 30 and over. The third category includes subjects who were untestable as well as those who failed to complete the test after scoring more than 29.

It is not claimed that these categories coincide with any clinical grading. The $\chi^{2}$ test was used to compare the categories with various health and social groupings.

Since age is significantly correlated with test score only those subjects aged 65-74 years at the time of the social survey are considered here. In this sample, neither age nor sex is significantly correlated with test score.

The factor most closely correlated with the score, even in this restricted age range, is the degree of peripheral arteriosclerosis (assessed clinically before the cognitive testing). The findings are shown in Table V.

TABLE V

LEARNING TEST SCORE RELATED TO PERIPHERAL ARTERIOSCLEROSIS

\begin{tabular}{|c|c|c|c|c|c|c|}
\hline \multirow{2}{*}{\multicolumn{5}{|c|}{ PALT Score }} & \multicolumn{2}{|c|}{ Vessel Wall } \\
\hline & & & & & Thick & Not Thick \\
\hline $\begin{array}{l}\text { Less than } 10 \\
10-29 . . \\
30 \text { and over } . .\end{array}$ & $\begin{array}{l}\ldots \\
\cdots\end{array}$ & $\begin{array}{l}\ldots \\
\cdots\end{array}$ & $\begin{array}{l}. . \\
\ldots\end{array}$ & $\begin{array}{l}\ldots \\
\cdots\end{array}$ & $\begin{array}{r}9 \\
16 \\
16\end{array}$ & $\begin{array}{l}28 \\
62 \\
17\end{array}$ \\
\hline
\end{tabular}

The only other factor which related significantly to the PALT score was the number of generations living in the household. Subjects from multigeneration households tended to have the lower (i.e., better) scores (Table VI).

TABLE VI

LEARNING TEST SCORE RELATED TO NUMBER OF GENERATIONS PER HOUSEHOLD

\begin{tabular}{ll|c|c}
\hline \multirow{2}{*}{ PALT Score } & \multicolumn{2}{|c}{ No. of Generations per Household } \\
\cline { 3 - 4 } & & One & More than One \\
\hline Less than 30 & $\cdots$ & 56 & 56 \\
30 and over & $\cdots$ & 22 & 8 \\
\hline
\end{tabular}

A similar trend appeared in relation to the number in the household, those in the larger households tending to have lower scores. However, this did not reach the conventional level of significance and of course the two factors are interrelated. These findings could be due to a naturally occurring selection process by which old people with impaired learning capacity tend to leave the hustle and bustle of the larger multigeneration households to live quietly alone or with one other person. Alternatively, the stimulation of living with others may have a beneficial effect on learning ability.

The following factors were not found to be significantly correlated with the test scores: age and sex (as previously explained), marital state, social class, education, whether working or not, area of residence, mobility, haemoglobin concentration, physician's estimate of physical health, physical disability score, giddiness, and purpura.

Although mobility was not correlated with the test score in this age range, when the complete 
sample is considered an association between mobility and a clinical rating of memory impairment was apparent. Half of the "definitely forgetful" (including the demented) were housebound, and half the housebound were definitely forgetful. Since, however, three-quarters of the "definitely forgetful" are aged 75 or over, this association disappears when those 75 and over are excluded.

\section{Prevalence of Psychotic Illness}

Four subjects exhibited a paranoid psychosis and two an endogenous depressive illness. With the ten dements this gives a figure of 7 per cent. (16 out of 228) who were suffering from a psychotic illness at the time of the visit. Primrose (1962), in his generalpractitioner study of a relatively isolated community in the north of Scotland, reports a prevalence rate for psychosis of 5.9 per cent. in the same age group. In my judgement, $5 \cdot 7$ per cent. (10 dements and 3 paranoid) were sufficiently disturbed to require compulsory medical treatment, should the social situation have warranted it. All 7 per cent. would have benefited (or their families would have benefited) from a community psychiatric service.

In-patients at the local psychiatric hospital aged 65 and over, who before admission had lived within the county borough boundary, were counted, the total being 128 . At the 1961 census just over 19,400 people in Swansea were aged 65 and over. If 7 per cent. were psychotic this suggests that for every person in hospital there were probably 10 with a psychosis living at home.

\section{Prevalence of Neurosis}

An estimate of the prevalence of neurosis was attempted. A 5-point clinical stability rating scale was applied to all 228 subjects, and the short form of the Maudsley Personality Inventory was given to the

TABLE VII

PREVALENCE OF NEUROSIS IN THE SAMPLE

\begin{tabular}{|c|c|c|c|c|c|}
\hline Group & $\begin{array}{l}\text { Clinical Rating } \\
\text { of Stability }\end{array}$ & $\begin{array}{l}\text { No. } \\
\text { rated } \\
\text { Clini- } \\
\text { cally }\end{array}$ & $\begin{array}{l}\text { Per } \\
\text { cent. }\end{array}$ & $\begin{array}{c}\text { No. } \\
\text { rated on } \\
\text { MPI }\end{array}$ & $\begin{array}{c}\text { Mean } \\
\text { Neuro- } \\
\text { ticism } \\
\text { Score }\end{array}$ \\
\hline 1 & (Most stable) $\quad \ldots$ & 21 & $9 \cdot 2$ & 21 & $2 \cdot 6$ \\
\hline 2 & & 71 & $31 \cdot 1$ & 67 & $3 \cdot 4$ \\
\hline 3 & & 102 & $44 \cdot 8$ & 92 & $3 \cdot 8$ \\
\hline 4 & $\begin{array}{l}\text { Neurotic symptoms } \\
\text { or a neurotic } \\
\text { adjustment in the } \\
\text { past } \quad . . \quad \quad . .\end{array}$ & 23 & $10 \cdot 1$ & 22 & $6 \cdot 0$ \\
\hline 5 & $\begin{array}{l}\text { Neurotic symptoms } \\
\text { or a neurotic } \\
\text { adjustment in the } \\
\text { past and at present }\end{array}$ & 11 & $4 \cdot 8$ & 10 & $6 \cdot 3$ \\
\hline Total .. & .. & 228 & 100 & 212 & 4.05 \\
\hline
\end{tabular}

212 subjects who were able to understand what was required, and were willing to co-operate (Table VII). The first three categories of the clinical rating are largely arbitrary and no attempt is made to define them.

The clinical rating indicates that only 4.8 per cent. exhibited neurotic symptoms (or evidence of a neurotic life adjustment) which had been present at various periods of the subject's life and were still present. A further $10 \cdot 1$ per cent. gave a history which suggested that they had experienced neurotic symptoms in the past which were currently absent. These subjects have a higher mean neuroticism score than the clinically stable subjects.

No cases of neurosis appearing for the first time in old age were identified. When new psychiatric symptoms developed at this age they did so in a setting of cognitive impairment or functional psychosis. It must be admitted, however, that the observer's preconceived ideas may have influenced the findings.

\section{The General Practitioners' Awareness of Psychiatric Disorder IN THE SAMPLE}

In addition to assessing the present mental state of the sample an inquiry was made about past psychiatric illness. Fourteen subjects ( 6 per cent.) were estimated to have probably had an affective illness at some time during their life. The fact that two were actually suffering from such an illness when seen suggests that this may be an underestimate.

To discover the general practitioners' awareness of psychiatric disorder in the sample a brief questionnaire was sent to the doctors of selected subjects. The questionnaire read as follows:

Would you please answer merely Yes or No to two questions about the following people on your list. Please endeavour to answer even if they are no longer your patients. The questions are:

(1) To the best of your knowledge, has this patient at any time in his/her life had a nervous breakdown or any form of mental or emotional illness, or a physical illness in which you believe psychological causes played an important part. (Include senile mental failure.)

(2) Have you or one of your partners ever treated the patient for "nerves". (Interpret "nerves" as broadly as you wish, but exclude organic disease of the nervous system.)

In a covering letter each doctor was asked to ensure that all partners in the practice saw the questionnaire. On the assumption that at least one positive reply indicated that the practitioner was aware of psychiatric abnormality in the subject, Table VIII compares the psychiatric diagnosis with the practitioners' awareness of psychiatric abnormality. 
TABLE VIII

GENERAL PRACTITIONERS' AWARENESS OF PSYCHIATRIC ILLNESS IN THE SAMPLE

\begin{tabular}{|c|c|c|c|c|}
\hline \multirow{2}{*}{ Psychiatrist's Diagnosis } & \multirow{2}{*}{$\begin{array}{l}\text { No. of } \\
\text { Cases as } \\
\text { assessed } \\
\text { by } \\
\text { Psychia- } \\
\text { trist }\end{array}$} & \multicolumn{3}{|c|}{$\begin{array}{l}\text { General Practitioner } \\
\text { Aware of Illness }\end{array}$} \\
\hline & & Yes & No & $\begin{array}{l}\text { Unknown } \\
\text { (No Reply) }\end{array}$ \\
\hline Dementia & 10 & 6 & 2 & 2 \\
\hline $\begin{array}{l}\text { Paranoid illness of psychotic } \\
\text { intensity other than in a } \\
\text { dement } \\
\text {.. }\end{array}$ & 4 & 3 & 1 & $\mathbf{0}$ \\
\hline $\begin{array}{c}\text { Anxiety neurosis currently } \\
\text { influencing behaviour }\end{array}$ & 4 & 1 & 3 & 0 \\
\hline Endogenous depressive illness & 2 & 0 & 1 & 1 \\
\hline $\begin{array}{l}\text { Psychosomatic illness currently } \\
\text { influencing behaviour }\end{array}$ & 1 & 0 & 1 & 0 \\
\hline $\begin{array}{c}\text { History of probable endo- } \\
\text { genous depression }\end{array}$ & 12 & 1 & 8 & 3 \\
\hline $\begin{array}{l}\text { History of mania } \\
\text { (or hypomania) } \ldots\end{array}$ & 2 & 0 & $1 *$ & 1 \\
\hline $\begin{array}{l}\text { History of confusional state } \\
\text { (within last } 10 \text { years) }\end{array}$ & 5 & 2 & 1 & 2 \\
\hline $\begin{array}{l}\text { History of psychosomatic ill- } \\
\text { ness with obvious psycholo- } \\
\text { gical precipitants .. }\end{array}$ & 3 & 0 & 2 & 1 \\
\hline Diagnosis doubtful .. & 10 & 3 & 5 & 2 \\
\hline
\end{tabular}

* The subject had been treated in the local psychiatric hospital.

Diagnoses based on history must be considered less accurate than those made when the subject was ill at the time of the visit.

A control group of 27 subjects, considered by the psychiatrist to have enjoyed good mental health, produced no positive replies. Dementia and paranoid psychoses seem to be satisfactorily recognized, but only one of the 14 cases of previous affective illness was recognized. Anxiety neurosis which was markedly influencing the subject's behaviour and way of life often passed unrecognized, as did past and present psychosomatic illness with what the author considered to be obvious psychological precipitants. The lack of awareness by general practitioners of affective illness amongst their patients is striking. There are, of course, factors involved here other than failure to recognize psychiatric illness. The doctor may be unaware of it because the patient has not presented himself or may have been attending another doctor at the relevant period.

The top half of Table VIII indicates that $9 \cdot 2$ per cent. ( 21 subjects) were markedly handicapped by a psychiatric condition present at the time of the visit. The practitioners were aware of psychiatric abnormality in approximately half of these. Omitting the cases of cognitive impairment one-third of the sample (73 out of 228) were experiencing or had experienced a condition of interest to a psychiatrist.

\section{SUMMARY}

Data are presented on the prevalence of psychiatric illness in a small but random sample of elderly folk living in their own homes. Investigation of the cognitive state included the use of a psychological test (PALT) as a check on the clinical opinion. An indication of the norm for age and sex, as estimated quantitatively by these test scores, is presented.

In the sample examined 4.4 per cent. were demented. There was a striking difference between the cognitive ability of men who had survived to the age of 80 and women of the same age, the men faring much better. Longevity may not account entirely for the fact that, in this sample, women dements outnumber the men by nine to one.

The main factors associated with cognitive impairment were ageing, peripheral arteriosclerosis (independent of age), and, to a lesser extent, residential isolation.

The prevalence of psychotic illness in the sample was assessed at 7 per cent. For each patient in the local psychiatric hospital there were probably ten persons with psychosis living at home. The prevalence of neurotic illness was estimated at about 5 per cent., and 9-10 per cent. of the subjects were found to be markedly handicapped by a psychiatric condition at the time of the survey.

The general practitioners' awareness of past and present psychiatric illness in the sample is discussed.

I wish to thank Prof. K. Rawnsley for his encouragement and constructive criticism at all stages of the study, and Dr J. G. Ingham for invaluable advice on the statistical problems. I am also indebted to the Joseph Rowntree Memorial Trust which has financed the enterprise, to my colleagues in the Social Science Department at Swansea University for much time-saving advice, to Prof. Max Hamilton for his help in preparing this communication, and to the general practitioners in Swansea. I am grateful to Dr T. P. Riordan, Medical Superintendent of Cefn Coed Hospital, for arranging to carry out the in-patient census. I would particularly like to record my gratitude to the old people of Swansea for their willing co-operation and generous hospitality.

\section{REFERENCES}

Caird, W. K., Sanderson, R. E., and Inglis, J. (1962). J. ment. Sci., 108, 368.

Gruenberg, E. M. (1961). "A Mental Health Survey of Older People". State Hospitals Press, Utica, New York. Cited by Kay and others.

Inglis, J. (1959). J. ment. Sci., 105, 440.

Kay, D. W. K., Beamish, P., and Roth, M. (1964). Brit. J. Psychiat., 110, 146.

Mann, H. B., and Whitney, D. R. (1947). Ann. of math. Statist., 18, 50.

Primrose, E. J. R. (1962). "Psychological Illness. A Community Study". Tavistock Publications, London.

Registrar General (1955). "Statistical Review of England and Wales for 1950-51. Supplement on General Morbidity, Cancer and Mental Health". HMSO, London.

Sheldon, J. H. (1948). "The Social Medicine of Old Age". (Nuffield Foundation).Oxford University Press,London. 